\title{
Diversified Network Effects on Innovation Performance in Tanzania: Innovation Strategy in Service Firms
}

\author{
Frida Thomas Pacho \\ Business Administration Department \\ Dongbei University of Finance and Economics
}

China

$\begin{array}{ll}\text { Received: February 9, } 2018 & \text { Accepted: April 12, } 2018 \quad \text { Published: May 30, } 2018 \\ \text { doi:10.5296/jebi.v5i1.12634 } & \text { URL: http://dx.doi.org/10.5296/jebi.v5i1.12634 }\end{array}$

\begin{abstract}
The study examined the issue of innovation with a focus on innovative diversified network in Tanzania service firms. The study aim was to assess the effect of diversified network which regarded as innovation strategy in firm's innovation performance. By empirically tested network variables named collaboration, information exploration and exploitation and technology acquisition. The regression results indicated information exploration and exploitation to be highly significant network over collaboration and technical acquisition in service firms in Tanzania. This imply that the service firms in Tanzania are tend to rely on information exploitation and exploration network compared to other networks such as collaboration and technology acquisition. The study made contribution to the literature regarding innovation in developing countries in service firms, non-patentable innovative firms in particular.
\end{abstract}

Keywords: Innovation; diversified network; Innovative service firms; Tanzania

Paper type: Research paper

\section{Introduction}

Firm innovative performance is widely recognized as one of the challenge entrepreneurs' face in their daily operations. This challenge persisted due to the lack of information from outside firms which if well explored and exploited would increase the ability of ventures to innovate and improve their performance. There is a chance for these challenges to be eliminated if entrepreneurs would open doors and apply the networking mechanism for innovative performance. The study by (Chesbrough, 2003) regarded diversified network as open innovation that deals with innovation capability of the firms by interaction with other firms. In an environment where entrepreneurs are faced with lack of information on technology and 
markets(Jensen, 2007; McGee \& Sawyerr, 2003), lack of financial instruments(Denis, 2004; Kwong, Jones-Evans, \& Thompson, 2012) to facilitate climate innovation and entrepreneurship and lack of management skills(Jennings \& Beaver, 1997) to full engage in continuously competitive business environment. These weaknesses addressed by prior author are suggested to be threat on survivor of entrepreneurs. However, many literatures suggest different types of activities in the network to improve innovation performance among entrepreneurs. The study by (Kotabe, Jiang, \& Murray, 2017) suggested that information exploration through political networking complements absorptive capacity in overcoming resources constraints as well as enhancing firms innovation. Other literature assume that first, the competitiveness of firms depends on external sources of knowledge and second, all firms in a certain are benefit from knowledge externalities(Boschma \& Ter Wal, 2007). But none of literature empirically assessed collaboration, information exploration and exploitation and technology acquisition as the entrepreneurs' diversified network which play the role on innovation performance. The study by (Rogers, 2004) which investigated the determinants of innovation by using networks and training suggested that the networks is associated with innovation in some sector-firm size category.

Prior literature defined a network as the ability to interact in the sense that scientist, technologists, marketing personnel, management and end user are likely to be involved in specific innovation activities from different organizational bases, both public such as University training and research lab and private such as consultancy and technology producer(Cooke \& Wills, 1999; Zeng, Xie, \& Tam, 2010). However, different type of innovation can be gained through different type of activities. Process, Service, organization and Marketing innovation have observed with EOCD to be among the types of innovations which can be used in service firms. Currently literature regarding innovation has broadened into two but related direction which are social networks and social responsibility (McManus, Holtzman, Lazarus, \& McManus, 2008) on innovation. Developing paths that take advantages of both internal and external (other firms) innovation. This development in innovation is referred to as 'open innovation' (Chesbrough, Vanhaverbeke, \& West, 2006; Parida, Westerberg, \& Frishammar, 2012).

However, recent studies highlight the importance of portfolio diversity, the extent to which the firm partners represent diverse source of knowledge-evidence on whether portfolio diversity is beneficial or harmful for firm innovation is mixed and inconclusive(Wadhwa, Phelps, \& Kotha, 2016). Then it leaves the gap to find out the influence of three types of diversified networks (which our study suggested as innovation network strategy) in innovation performance in Tanzania service firms. These kind of diversity networks has observed in prior literature as knowledge resources which can be available to a firm in its portfolio of collaborative interfirm relationships. Gao and Wang suggested that benefits from networks may evolve duration hence firms should search for optimal network configurations(Wang \& Gao, 2011). This paper consists of the following framework. Section two discusses theoretical and empirical framework which presented the arguments about innovation concept, service firms and innovation, network as innovation channel with deep investigation in the literature regarding the influence of collaboration, technology acquisition 
and information exploration and exploitation in innovation performance. Hypothesis of the study also presented in section two. Section three discusses the research methodology for the study which presents the research model. Section four comprises of data analysis and results and section five comprises of discussion and conclusion.

\section{Theoretical and Empirical Framework}

\subsection{Innovation Concept}

Innovation can be defined as the winning social or commercial ideas, where the idea is complete brought to the market successfully by offering a more updated or effective alternative solution to existing arrangement. In the oxford Handbook of innovation the concept of innovation refers to putting into practice of inventions. A broader approach regards to innovation as not only the development of new products, new processes and new source of supply but also the exploitation of new markets and development of new ways to organize business (De Jong \& Vermeulen, 2006; McAdam, McConvery, \& Armstrong, 2004; Naudé, Szirmai, \& Goedhuys, 2011; Rosenbusch, Brinckmann, \& Bausch, 2011). Innovation is crucial in the society because it's the fundamental source of competition in modern-knowledge-based economy. Not only increasing standard of living but also contributes solution to the society as well as environmental challenges. There are multiple types of innovation in business; that can be related to new products or services, new products processes, new marketing techniques and new organization and managerial structure (Arundel \& Kemp, 2009). Innovation can also be defined as the setting up of a new production function. This covers the case of a new commodity as well as those of a new form of organization such as merger, of the opening up of new markets and so on (Schumpeter, 1934). Innovation is a continuous process. Firms constantly make changes to products and processes as well as collect new knowledge, and it is more difficult to measure a dynamic process than a static activity(Oecd, 2005; Rosenbusch et al., 2011). In addition, Oslo defined innovation as the implementation of a new or significantly improved product (good or service), or process, a new marketing method, or a new organizational method in business practices, workplace organization or external relations.

The book by (Lundvall, 1992) has described that one of our starting point is that innovation is a ubiquitous phenomenon in the modern economy. In practically all parts of the economy and at all times, we expect to find ongoing process of learning, searching and exploring which results in new products, technics, forms of organization and new markets. Back on days Peter Drucker argues that innovation is real work that can and should be implemented and managed like any other corporate functions, thus success should be from the systematic pursuit of opportunities than from a flash of genius (Drucker, 1985). Different types of innovation has clarified in literatures (Damanpour, Walker, \& Avellaneda, 2009; Gunday, Ulusoy, Kilic, \& Alpkan, 2011; Oke, 2007). There are products, process, radical and incremental innovation types which are mentioned in the prior literature. Product innovations described as new or improved products or services, product or service must be new or improved with respect to its capacity, user friendliness, and input components of subsystems. Process innovations are new or significantly improved production methods, marketing or distribution methods as well as 
new or improved ways of organizing activities. Radical innovation refers to product that were new to the market (i.e. with the firm being the first to introduce the innovation on its market which does not necessary have to be the world market). Incremental innovation talks of products that were new to the firm but not new to the market (Naudé et al., 2011).

Suggested type of innovation by Oslo Manual (Bloch, 2007) is as follows: First is product innovation; new or significantly improved with respect to its characteristics or intended usage. Improvement includes components and materials, technical specifications, incorporated software, user friendliness or other functional characteristics, if its product innovations can utilize new knowledge or technologies or can be used on new uses or combinations of existing knowledge or technologies. Second type addressed is the implementation of new or significantly improved production or delivery method. This includes significant change in techniques, equipment and/or software. Process Innovation can be intended to decrease unit costs of production or delivery, to increase quality or to produce or deliver new or significantly improved products. Third is marketing innovation is the implementation of new marketing method involving significant changes in product design or packaging, product replacement, product promotion or pricing. Marketing innovation is aimed at better addressing customer needs, open up new markets or newly positioning a firm's product on the market with the objective of increasing the firm's sales. And forth is an organizational innovation in implementing of new organizational method in the firm's business practices, internal or external relations. The intention can be to increase a firm's performance by reducing administrative costs or transaction costs, improving workplace satisfaction (and thus labor productivity), gain access to non-tradable assets such as non-codified external knowledge or reducing cost of supplies(Bloch, 2007).

\subsection{Service Firms and Innovation}

The importance of innovation in the services sector and its contribution to economic growth is increasingly acknowledged and has led to a multiple number of studies on innovation in services (De Jong, Bruins, Dolfsma, \& Meijaard, 2003; Hauknes \& Rj, 1998; Howells et al., 2004). There is an increasing of literatures regarding service innovation. But on the past, service efforts were not considered as the innovation at all (Daniel Kindström, Nätti, Hurmelinna-Laukkanen, \& Johnston, 2014). This was occurred due to its low share of R\&D expenses, lack of reflectivity of service innovation caused by the fact it happens in numerous parts of companies, and continuous improvements than observable technological changes (Hurmelinna-Laukkanen \& Ritala, 2010). Service products lack storage feature so customers have to consume at the moment of production; thus, consumers are involved in the production process. This participation or involvement of the consumer in the act of production is at the core of the services production process and is termed as coproduction. Moreover, services are heterogeneous in a fact that each act of production is a new experience due to the active participation of consumers. These characteristics, which all services share, make it difficult to calculate the output these firms produce, and hence their innovation (Evangelista \& Sirilli, 1995; Tether, 2005). All the assumptions has been proved wrong due to the fact that innovation may happens in varying context as the same as products. In value addition of the last statement, network aiming at service innovation has been 
increasing their importance during the recent years (Rubalcaba, Michel, Sundbo, Brown, \& Reynoso, 2012). Take into account all these, still the nature of service innovation is still pretty limited (Ngo \& O'Cass, 2013) thus there are still few research concerning service compared to products. The study by (Faïz Gallouj \& Weinstein, 1997) provided a typology of innovation in services based on six different innovative modes, which depend on the type and depth of transformations that occur in the service product: (a). radical; deep transformations that replace the new system of service, (b). improvement; some characteristics improved without changing the structure of the system, (c). incremental; new elements introduced or substituted that marginally change the system,(d) formalization; order and specify characteristics through standardization,(e). Recombinative; systematic reutilization of components of the system keeping the core design concept, and (f). Ad hoc; interactive creation of a solution to a particular demand. The traditional difficulty in collecting data from services has now being improved, and nowadays, innovation in services is well-thought-out an important field of research. There has been much literature interest in this subject in the past decade(Evangelista, 2000; Faiz Gallouj, 2002; Tether, 2005) also proposed a service innovation typology matrix that consists of the following four quadrants: incremental service innovation, relative service product innovation, relative service process innovation, and radical service innovation. Drawing on the concept of innovation, service innovation can be defined as "the introduction or bring of any new service to market (service product innovation) or the introduction of a new service production process internal to a service organization to produce a new or an existing service product (service process innovation). Most of the prior study are not empirically assessed. The study aim is to empirically investigating different three types of activities which can be used as innovation network strategy to improve innovation performance in service firms. And innovations which are regarded here are Service innovation, process innovation, marketing innovation and organization innovation.

\subsection{Network as Innovation Channel}

Literature considered networking or channeling as a strategy to attract resources, skills and information, to help reduce uncertainty and further shape the direction of a business' actions. The study by (Bamieh, Jovanovic, Mitra, \& Patterson, 2012; Dhanaraj \& Parkhe, 2006; Lee, Park, Yoon, \& Park, 2010) gave reasons to why networking is important for entrepreneurs: 1) A business can find legitimacy in a network, protect their new products and services, and gain knowledge and attract investments, 2) entrepreneurs need to know governance structures and have a network in systems and institutions to be able to establish themselves, and 3) the emergence of the internet has become an important part of networking, as the reliance on intellectual capital for creating new products and services is constantly increasing, and connects millions of people (entrepreneurs, users and others). Networking is one method which gives firms ability to innovate. Whether it is indirect or direct social contact with individuals, groups or institutions, its advantageous to entrepreneurs cause will give the possibility to gain access to affective resources, informative resources and material resources(Spilling,2008). Our study has aimed to examine three type of activities which can be used as the network strategy for innovation performance. These three activities are 
discussed in the literature as follows;

\subsubsection{Collaboration Network and Innovation Performance}

In previous to current literatures it's clear that organization can improve their capabilities by developing interfirm collaborations with a number and variety of partners. These collaborations have been discussed in different literatures such as collaborating with suppliers or vendors or customers (Baldwin \& Von Hippel, 2011; Tsai, 2009; Von Corswant \& Tunälv, 2002) with potential, existing industry competitors and rivals(Tsai, 2009). Cetindamar and Ulusoy in their study in manufacturing firms in Turkey said, the main partners on collaboration tends to be suppliers and customers (Ulusoy, Çetindamar, Yeğenoğlu, \& Bulut, 2007). There are number of known reasons out of collaborations. Faems has labelled collaboration with customers and suppliers or vendors as exploitative is associated positively with higher level of turnover stemming from improved products(Faems, Van Looy, \& Debackere, 2003). Although the study based on technological partnership in advanced countries, the results show that institutions used different type of collaborations for specific reasons. Another reason can be the type of innovation determines the decision to collaborate. Sanchez and Martinez in their findings shows firms which innovate in process and introduce innovations are more likely to collaborate in $R \& D$. More results shows that it's unlikely for a small firm to participate in R\&D if there is no public fund (Martínez - Sánchez, Vela - Jimé nez, Pérez - Pérez, \& De - Luis - Carnicer, 2009). Collaborations might be risk reductions associated with R\&D intensive innovation project significantly (Hagedoorn, 2002; Veugelers, 1998). Resource dependence theory suggested that "Choose the least constraining device to administer relations with your external partners that will allow you to maximize uncertainty and dependence and maximize your autonomy. If dependence comes from relying on sole-source supplier, then an obvious solution is to find and maintain alternatives" its standard practice in manufacturing (Davis \& Adam Cobb, 2010). This theory shows that firms are dependent to external environment for access to necessary resources both tangible and intangible resources for survival and growth. The more the resources need the more competition the firm faces form external environment, the stronger the incentive will be for firm to act to ensure control to the needed resources. Means that interfirms collaborations imply access to complementary assets needed to innovation projects more successfully (Bougrain \& Haudeville, 2002; Hagedoorn, 1993; Teece, 1986). Boring and Thune in the their study shows that firms 'reasons to collaborate with universities are same which are development of broader competencies, knowledge in core technological areas, R\&D competencies and innovation capability were key results in all firms. By collaborations, transfer of codified and tacit knowledge can be achieved(Miles, Miles, \& Snow, 2005; Spekman, Salmond, \& Lambe, 1997).

Despite the success of collaborations, empirical studies confirms disadvantages if collaborations not managing successfully, for example misinformation and misinterpretation of intended contract and benefits (Lam, 1997; Larson, 1992). But if successful managed can bring about wise access of social, technical and commercial competitive resources which otherwise might take years of operation to gain (Kotlarsky \& Oshri, 2005; Teece, 1986). In additional to that, if it is well managed interfirms collaboration contribute to innovation 
effectiveness of firm involved (Tether, 2002). And finally EOCD confirmed transfer factors that are those which strongly influence the effectiveness of the linkages, flows of information and skills, and absorption of learning which are essential to business innovation - these are factors or human agents whose nature is significantly determined by the social and cultural characteristics of the population. Previous literatures have proved collaboration have positive changes to innovation performance of the firm. In this study collaboration is one among network activities chosen to test its efficiency as a strategy to improve innovation in service firms.

\subsubsection{Technology Acquisition and Innovation Performance}

Technology acquisition is said to be one of the strategy which can assist service firms to fuel innovation (Ahuja \& Katila, 2001). The study by (Tsai, 2009) recognized technology acquisition from the network can be used in the firm to improve innovation, as a result leading to a faster market entry. This kind of network can be done through purchasing patents, franchising purchasing activities which done externally in order to acquire technology or knowledge from other firms. One of the reasons for firms acquiring technology is efficiency and quality improvement. Hui Ling Huang (2013) empirical findings demonstrate the alignment between service innovation and strategic use of Information Technology (IT) has significant impact on service innovation performance and business performance. By franchising or patent right purchase mean that sources such as technology or knowledge obtaining through this network is more specific and give specific solutions compared to searching channels. However, technology acquisition have a significant positive impact on an innovation performance only when firms have internally available resources (Jones, Harrison, \& McLaren, 2001) an absorptive capacity (Huang \& Rice, 2009) or significant internal R\&D capacity (Tsai, 2009; Tsai \& Wang, 2008). Also for technology acquisition network acquisition to be legit, there should be contract agreement between the buyer and seller (Frenz \& Ietto-Gillies, 2009). And by this means this kind of network produce considerable transaction costs such as connection, execution and negotiation costs.

\subsubsection{Information Exploration and Exploitation and Innovation Performance}

There are multiple ways a firm can be used to obtain or capture information. The study by (Katila \& Ahuja, 2002) recommended two dimensions to better capture a firm's search behavior. Search depth and search scope. Search depth is the degree to which search reconsiders a firm's prior knowledge. Searching behavior can be grouped as exploration and exploitation. This reflects a firms' ability or capability in explore new opportunities for existing knowledge elements (Fosfuri \& Tribó, 2008; Katila \& Ahuja, 2002).On the other hand search scope means the degree of new knowledge that is explored, which captures a firm's willingness and capability in exploring and integrating new ideas, which in another way be called absorptive capacity(Cohen \& Levinthal, 1990; Fosfuri \& Tribó, 2008). Then March defined information exploration as experimentation of new alternatives (March, 1991). It's well known that firms that involved in exploration and integrate novel, emerging and pioneering technologies into their operations will be more likely to generate influential knowledge than firms engage in more limited local search processes (Ahuja \& Morris 


\section{Macrothink}

Lampert, 2001). Many literatures suggested the need for a balance between information exploitation and exploration.

\subsubsection{Diversity Theory}

The consideration on this study is the influence of both breadth and depth of knowledge accessible by the firm in its portfolio on innovation performance. Increasing compositional diversity of a firm's partner provides it with greater access to diverse knowledge beyond firm's boundaries (Baum, Calabrese, \& Silverman, 2000). Means increase portfolio diversity presents both increasing benefits and challenge to firms' innovation (Phelps, Heidl, \& Wadhwa, 2012). The prior research presented inconsistent results on this. Prior research indicate that the depth of partners' technological knowledge stocks increase interfirms learning and firm innovation performance by increase the volume and richness of knowledge available for recombination(Baum et al., 2000). Moreover, interfirm network research show that the firm innovation performance rises as the volume of knowledge spillover its partners have access to as the result of their own interfirm ties increases(Ahuja, 2000). Increasing search scope(breadth) facilitate the identification of potential knowledge elements for recombination, while depth allow the researcher to investigate more deeply and better understanding the difference knowledge domains, thereby increasing the ability of the searcher to integrate and combine the knowledge with its own(Gavetti \& Levinthal, 2000; Katila, Rosenberger, \& Eisenhardt, 2008). Currently, when the open innovation emphasized, the concept of network or channels or chain is proposed in terms of different types of channels and number of pathways of exchange between a firm and its external and internal environment rather than towards the degree of interaction within each type of channel (Laursen \& Salter, 2006). For this case the significant discriminating characteristics among the type of source have highlighted which have its own influence on innovation performance (Nieto \& Santamaría, 2007). First, vendors may simplify by building new methods of reducing product lead times and identify if there is potential technical error (Chung \& Kim, 2003). Second, Customers or clients can assist identify market opportunities and provide new solution ideas by defining their needs in the pre-launch development stage, or by list their requirements in the form of post-launch improvements(Rothwell, 1994). Moreover, firm can identify their rivals mistakes or problems with their innovation processes. In additional to that, research firms such as universities and research centers can provide firms with new scientific technology and knowledge for product and process innovation by interacting both formally and informally(Caloghirou, Kastelli, \& Tsakanikas, 2004; Christensen \& Drejer, 2005). And therefore sources through available channels can influence innovation chances (Caloghirou et al., 2004). Thus firms are not limited to the number of channels or network and should consider multiple number of network to improve innovation. Use of multiple network for innovation performance is crucial regardless of the type of the network (Amara \& Landry, 2005). 


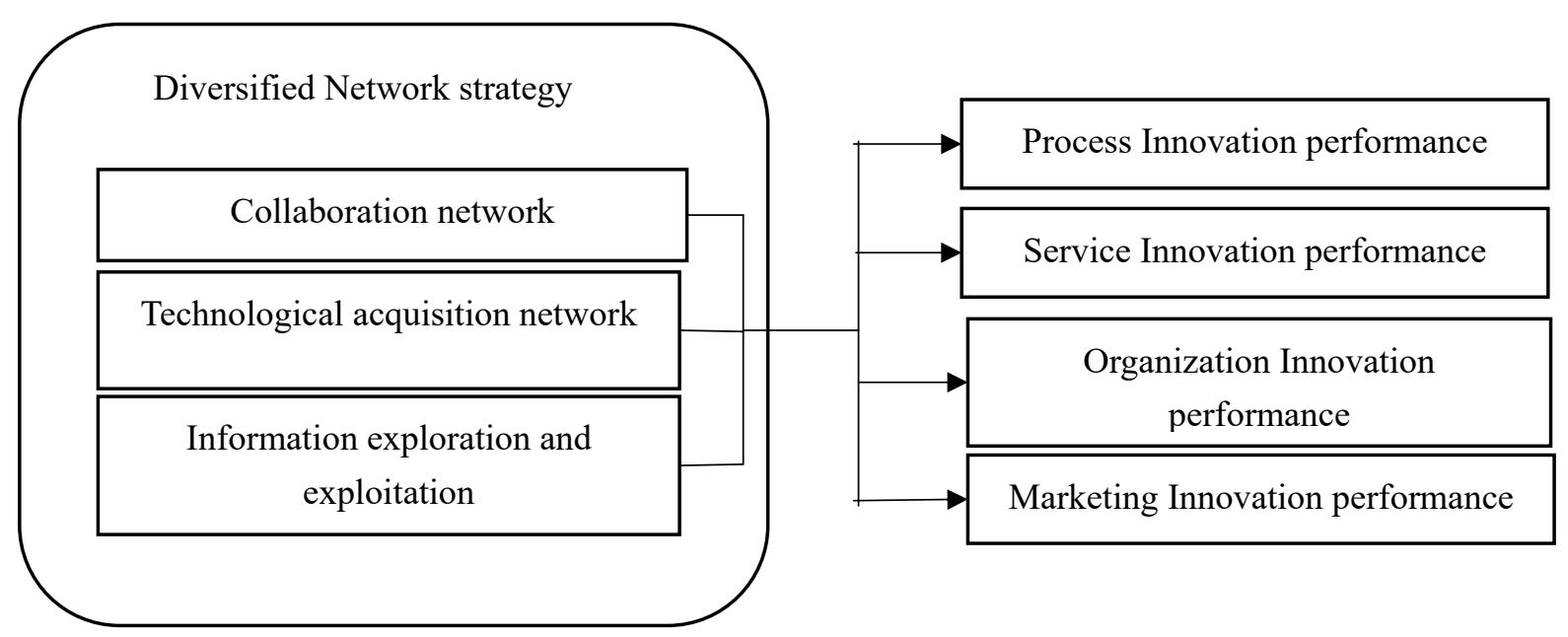

Figure 1. Theoretical Framework

\subsection{Hypothesis}

Based on the theory from previous literature, our study suggested the following hypothesis to be tested:

1. There is positive impact on Service innovation performance if service firms employ diversified network strategy.

2. There is positive effect on Process innovation performance if service firms employ diversified network strategy.

3. There is positive effect on marketing innovation performance if service firms employ diversified network strategy.

4. There is positive impact on Organization innovation performance if service firms employ diversified network strategy.

\section{Research Methodology (Research Design \& Data Collection)}

\subsection{Research Model}

The author establishes models which based on multiple regression analysis. These models measure the degree of impact of certain independent variables on dependent variables while other independent variables are controlled (Allison, 1999). This model gives a chance to make a comparative analysis among independent variables and discern precise causal relationship. Four types of Innovation such as Service/product, process, organization and marketing are used as dependent variable in terms of innovation performance. Interaction explained by diversified network are assumed to be able to heighten the four type of innovation performance. This allows to allocate network diversity as independent variables. These are diverse sources as accessed through the network. These are collaborations network, information exploitation and exploration network and technology acquisition network. The following are models which are regression in nature are applied.

Model 1: Process Innovation Performance 
ProcIP $=\beta o+\beta 1$ InfoE $\& E+\beta 2$ Colla $+\beta 3$ TechAc $+\beta 4$ Firm size $+\beta 5$ Training $+\beta 6 R \& D$

Model 2: Service Innovation Performance

ServIP $=\beta \mathrm{o}+\beta 1$ InfoE $\& \mathrm{E}+\beta 2$ Colla $+\beta 3$ TechAc $+\beta 4$ Firm size $+\beta 5$ Training $+\beta 6 \mathrm{R} \& D$

Model 3: Marketing Innovation Performance

$\mathrm{MktIP}=\beta \mathrm{o}+\beta 1$ InfoE $\& \mathrm{E}+\beta 2$ Colla $+\beta 3$ TechAc $+\beta 4$ Firm size $+\beta 5$ Training $+\beta 6 \mathrm{R} \& D$

Model 4: Organization Innovation performance

OrgIP $=\beta \mathrm{o}+\beta 1$ InfoE $\& E+\beta 2$ Colla $+\beta 3$ TechAc $+\beta 4$ Firm size $+\beta 5$ Training $+\beta 6$ R $\& D$

Notation are explained as follows: ProcIP=Process Innovation performance, ServIP=Service Innovation Performance, MktIP=Marketing Innovation Performance, OrgIP $=$ Organization Innovation performance, InfoE\&E $=$ Information Exploitation and exploration, Colla=Collaboration, $\quad$ TechAc $=$ Technology Acquisition and $\mathrm{R} \& \mathrm{D}=$ Research and Development

\subsection{Sampling Frame and Data Collection}

The sampling frame for this study was small and medium service firms. We randomly selected 173 service firms participated in "Enterprise survey" which secondary information obtained in Tanzania Bureau of statistics database. Secondary data such as year of establishment obtained from there as well. Simple random sampling adopted by stratified sampling that allowed to select 150 elements. These are firms which have from 5 or more employees to meet Oslo standards and three years or more since establishment. Year of establishment is crucial so that the company to qualify being in innovation survey. Three years is recommended time by (Oecd, 2005). OECD recommended three years due to the explanation that innovation is a time dependent process (Castles, 1997). To obtain primary data self-administered questionnaire were sent to firms by email which we sent two another reminder emails and only 104 (69 percent response rate) questionnaire were returned. The author considered multiple data source because they improve reliability and validity (Yin, 2003). Tashakkori and Teddlie (2003) argue that multiple methods are useful if they provide better opportunities for you to answer your research questions and where they allow you to better evaluate the extent to which your research findings can be trusted and inferences made from them.

\subsection{Measures}

Measuring innovation depends on how each organization or country perceived innovation to be (Tin, 2005). Consistent with past research author defines innovation as the act of introducing something new or potentially improving the existing ones(Oslo,OECD,2005). The purpose of research is to determine whether the diversity of the three network types impact the four types of innovation performance. And four innovation performance measured by the change and establishment of new activities as the result of information exploitation and exploration network, collaboration network and technology acquisition network. Unlike other authors used dichotomous variables in their studies on innovation performance most of the 
times measuring whether a new product had been developed by a firm, or not, regardless to its degree of novelty (Ortiz-de-Urbina-Criado, Montoro-Sánchez, \& Mora-Valentín, 2012; Vega-Jurado, Gutiérrez-Gracia, \& Fernández-de-Lucio, 2009). Three years is recommended time from OECD. OECD recommended three years due to the explanation that innovation is a time dependent process (Castles, 1997). Key drivers or indicators of performance are defined ex ante and then measured after a certain time period has passed (Opinion paper-Detecon International GmbH, 2012). Omary and Lewrick, 2010, Cho and Choi, 2011 measured the degree of innovation performance by amount of radical and incremental innovation realized.

\subsubsection{Dependent Variables}

Dependent variables are Service innovation, Process Innovation, Organization innovation as well as marketing innovation. Process innovation performance can be defined as improved of existing method or application of new method of supplying services and delivering products or service production technology to increase productivity. Process innovation performance measured by 8 items such as (1.) Introduction of new logistics channel, (2) Improving the existing logistics channels, (3) Improving of the existing purchasing system, (4) Introduction of new purchasing system, (5) Introduction of new accounting system, (6) Improving of existing accounting system, (7) Introduction of new automated facility (such as Bar Code etc.), (8) Improving of existing automated system.

Service innovation performance can be defined as the establishment of new service or significantly improved service which as the result can add value to firm's turnover. Therefore service innovation performance is measured by the number of new or significantly improved service introduced by service firms. If a firm continuously improves or advances existing products or services and introduces new but related generations, it is more likely that these products will be developed with customer needs in mind (Christensen 2000).

Marketing innovation performance can be defined as establishment of new or significantly improved methods that contribute to increased attractiveness and competence of service or recognition of clients in terms marketing or selling products(such as more improvement of display in shops(or shop malls) or creating e-marketplaces). Can be counted by 1.Service design and concept 2. Brand, logo, name, trade mark 3. After sale services 4.Advertising methods 5.Promotion of the service 6.Pricing strategies including discount scheme and 7. Customer loyalty reward. (World Bank enterprise innovation database 2012, Oslo Manual, 2005).

Organization innovation performance can be defined as the improvement of existing methods or establishment of new methods in the organization. The measurement including new introduced or significantly improved of (1) decentralization of planning, controlling and operating function (2) job training or internal knowledge sharing (3) Job flexibility or inter-functional collaboration (4) outsourcing of specific functions or insourcing (5) New method of hiring (6) Reduction of hierarchical level (7) Job enrichment/Job enlargement (8) Continuous improvement process (Kaizen). 


\subsubsection{Independent Variables}

Dependent variables are regressed by (1) diversified technology acquisition network and (2) collaboration network and (3) Information exploitation and exploration. The clarifications of these diversified networks are as follows: First, Technology acquisition network activity refers activities on networking with vendors or dealers who offer technology and knowledge such equipment, software and machinery needed, patents, licenses, franchise, copyright and R\&D. Technology acquisition has 8 activities networks used for innovation on this study.

Second, Collaboration is another diversified network activity which partnered with firms in innovation projects or research. This study regarding collaborations with similar type of partners (e.g. multiple research institutions) as one single illustration.

Third is Information exploration and exploitation refer to kind of sources which used by the firm through information network in the progress of innovation activities. Information exploration and exploitation are divided into four groups and are total of 18 sources. These variables adopted from Chi and Choi (2011).

\subsubsection{Control Variables}

The models contain control variables. These are variable which held constant to gain the perfect results in the process. In this study control variables were training, research and development and firm size. Firm size in this study was controlled although in previous research was used as independent variable related to innovation (Cho, 2011 Huang and Rice, 2009). Capability of large firm to acquire complementary assets which will smooth the commercial success of their innovation performance (Tripsas, 1997) is high compared to small firm. If in the study firms' size categorized as small firms and large firms. The firms' size was dummy variable with a value of 1 if it's large otherwise 0 .

Intensity of internal R\&D is represented the capability of firms' technical level from internal $R \& D$ investment (Rogers 2004). In the $R \& D$ the categorization was if firm is performing $\mathrm{R} \& \mathrm{D}$ inside the company or outside or none. If performing inside is most active, if performing outside less active and if no R\&D activity.

Training was another control variable. More trained firms can influence the innovation results than less trained firms. The Training considered percentage of the employees participating in internal or external training for 3 years. $1=1-10 \%, 2=11-20 \%, 3=21-30 \%, 4=31-40 \%, 5=$ over $50 \%$

\section{Data analysis and Results}

The data analyzed using linear regression and the first test done was correlation between dependent and independent variables. The correlation provides the indication that there is relationship between two sides of variables (Julie Palant 2002, 2005). The dependent variables which are Process innovation performance, Service innovation performance, Marketing innovation performance and organization innovation performance are positively correlated with Information exploration and exploitation, Collaboration and Technology acquisition, training, R\&D activities and company size. This indicates that the four types of 
innovation are positive correlated with independent variables as well as control variables. By this it means firms should focus on all four type of innovations to be able to improve performance in their services.

Moreover, Model 1 was used to examine the effect of diversified network strategy in process innovation performance. In models evaluation Adjusted $\mathrm{R}$ square was used. Adjusted $\mathrm{R}$ square tested the percentage of explained variation that if all independent variables in the model affect the dependent variable. In other words it tells how much of the variance in the dependent variable is explained by the model. In this case the model 1(table 2) explains $0.410(41 \%)$ at $0.041(\mathrm{P}<0.05)$ of the variance in perceived stress. In other words $41 \%$ was the percentage that the model well explained the variability of the response data around the mean. On the model 2 the aim was to find out the impact of diversified network strategy in service innovation performance. The adjusted R-square result of the model was $0.753(75 \%)$ at 0.000 $(\mathrm{P}<0.01)$ which means the model was well explained the variability of the response around mean. The third model was identify if there is an effect on marketing innovation performance by employing diversified network strategy and the adjusted R-square was $0.408(41 \%)$ at $0.002(\mathrm{P}<0.01)$ and the fourth model's aim was to measure the impact of diversified network strategy on organization Innovation performance and adjusted R square was $0.4(40 \%)$ at $0.003(\mathrm{P}<0.01)$. Author preferred adjusted R-squared because it provides an unbiased estimate of the population R-squared. In conclusion regarding the models all of them provided the respectable results compared to the results reported by Cho, Park and Choi (2011).

However, in testing which variables included in the models contributed highly to the prediction of the dependent variables the Beta under standardized coefficients was used (table 1). In the model 1. Information exploration and exploitation highly contributed by 9.871 at $0.000(\mathrm{P}<0.01)$ level of significance, technology acquisition contributed by 1.304 at 0.039 $(\mathrm{P}<0.05)$ level of significance and collaboration contributed by 2.574 at $0.006(\mathrm{P}<0.01)$ level of significance. In the model 2. Information exploitation and exploration highly contributed by 5.659 at $0.000(\mathrm{p}<0.01)$ level of significance, Technology acquisition which was 3.188 at $0.029(\mathrm{P}<0.05)$ level and collaboration contributed by 0.482 at $0.041(\mathrm{P}<0.05)$ level. In the model 3 Information exploitation and exploration highly contributed by beta of 6.207 at $0.000(\mathrm{P}<0.01)$ level, Technology acquisition contributed by 3.590 at $0.023(\mathrm{P}<0.05)$ and collaboration contributed by 0.505 at $0.081(\mathrm{P}<0.10)$ level of significance. In the model 4 again Information exploitation and exploration contributed highly by beta 6.016 at $0.000(\mathrm{P}<0.010)$ level of significance, technology acquisition contributed by 3.552 at $0.022(\mathrm{P}<0.05)$ level of significance and collaboration contributed by 0.632 at $0.088(\mathrm{P}<0.1)$ level. To conclude on this, the information exploitation and exploration made the strongest unique contribution to explain dependent variables in all models and collaboration contributed less. 
Table 1. Regression results for four research model (beta coefficient)

\begin{tabular}{|c|c|c|c|c|c|c|c|c|}
\hline \multirow[t]{2}{*}{ Variables } & \multicolumn{2}{|c|}{$\begin{array}{l}\text { Model } 1 \\
\text { Process } \\
\text { Innovation } \\
\text { Performance }\end{array}$} & \multicolumn{2}{|c|}{$\begin{array}{l}\text { Model } 2 \\
\text { Service } \\
\text { Innovation } \\
\text { performance }\end{array}$} & \multicolumn{2}{|c|}{$\begin{array}{l}\text { Model } 3 \\
\text { Marketing } \\
\text { Innovation } \\
\text { Performance }\end{array}$} & \multicolumn{2}{|c|}{$\begin{array}{l}\text { Model } 4 \\
\text { Organization } \\
\text { Innovation } \\
\text { Performance } \\
\end{array}$} \\
\hline & Beta & Sig & Beta & Sig & Beta & Sig & Beta & Sig \\
\hline Information & 9.871 & $0.000^{* * *}$ & 5.6590 & $\begin{array}{l}0.000^{* *} \\
*\end{array}$ & 6.207 & $0.000^{* * *}$ & 6.016 & $0.000^{* * *}$ \\
\hline Collaboration & 2.574 & $0.006^{* * *}$ & 0.482 & $0.041^{* *}$ & 0.505 & $0.081^{*}$ & 0.632 & $0.088^{*}$ \\
\hline Technology & 1.304 & 0.039 & 3.188 & $0.029 * *$ & 3.590 & $0.023 * *$ & 3.552 & $0.022^{* *}$ \\
\hline Training & 0.001 & 0.011 & 0.9133 & 0.000 & 0.408 & 0.000 & 0.532 & 0.000 \\
\hline$R \& D$ & 0.261 & 0.009 & 0.919 & 0.025 & 0.769 & 0.77 & 0.828 & 0.57 \\
\hline
\end{tabular}

Table 2. F, R, R square, Adjusted R square, S and Pvalue

\begin{tabular}{lllllll}
\hline Models & $\mathrm{F}$ & $\mathrm{R}$ & Rsquare & $\begin{array}{l}\text { Adjusted } \\
\text { R sq. }\end{array}$ & $\mathrm{S}$ & Pvalue \\
\hline $\begin{array}{l}\text { Process } \\
\text { Innovation }\end{array}$ & 22.855 & 0.658 & 0.433 & 0.410 & 1.44513 & 0.040 \\
$\begin{array}{l}\text { Service } \\
\text { Innovation }\end{array}$ & 87.678 & 0.873 & 0.763 & 0.753 & 1.535 & 0.000 \\
$\begin{array}{l}\text { Marketing } \\
\begin{array}{l}\text { Innovation } \\
\text { Organization }\end{array}\end{array}$ & 22.360 & 0.656 & 0.431 & 0.408 & 1.54249 & 0.002 \\
Innovation & 22.445 & 0.651 & 0.424 & 0.400 & 1.53356 & 0.003 \\
\hline
\end{tabular}

Predictors: Training, Research and Development Activities, information, collaboration, technology.

\section{Discussion and Conclusion}

The main objective of the study is to examine the relationship of the network diversity such as collaboration, information exploration and exploitation and technology acquisition in four types of innovation. The study based on service firms in Tanzania. And according to the results information exploration and exploitation confirmed to contribute greatly in four types of innovation performance than any other diversified network activities. By considering the organization goals, service firms prefer information feedbacks from customers and other different stakeholders to improve their service and customers experience. Unlike manufacturing firms which are greatly focus on product development and production. It might be hard to identify the network actors and determining what kind of knowledge to be imported in the innovation process or when and where an innovation is generated (Arrow 1974) but in service firms to innovate, needs more knowledge from their stakeholders outside the firm and information exploitation and exploration proved to be the main preferred 
channel. The firm investigated are those which are independent and can be able to make decisions. The study has confirmed information flow to be the main knowledge resource in service firm because of the nature of the service firms compared to other type of firms. Among four types of innovations, information exploitation and exploration contributed highly (coefficient of 9.871) on process innovation than it does on other types of innovation performance. The reasons confirmed with different literature as follows: Firstly Service is inseparable and cannot be stored, customers have to consume at the moment of production and consumption have to coincide in time and space (Hortelano, Moreno, 2007). This means consumers are involved in the production process and therefore getting feedbacks from consumers is an innovative move to improve innovation performance. Thus by having knowledge how others are providing and improving their services help firms to innovate. And this can be obtained through information exploration and exploitation. Secondly, as inputs for services need the producer to participate, and the type of inputs require during the delivery of services are depending on the transformation process type adopted by the organization (Agya, Harjit, Selchon 2014), firm confirmation of which one is innovative process to compete in the market need detailed information through channels. Unlike Cho and Choi (2011) tested which confirmed information to have great impact in marketing innovation performance.

This study confirmed collaboration and technology acquisition networks have lower significant contribution in all kind of innovations researched in the study. This is as the results of the nature of developing countries itself. Tanzania in particular face multiple challenges regarding technology and innovation knowledge. The country haven't shown any effort to come up with innovation policy which can guide firms what to do to innovate. The challenge are in good education and skills, the challenges regarding weak link between academic institutions, private and public research institutions and weak of governance such as lack of policy coordination and commitment to innovation issues. In other words Tanzania has policy issue which hinder the implementation of in house innovation activities versus collaborative innovation activities or technology acquisition activities on the innovative performance of firms (Zaparucha \& Muths, 2014). There is also an absence of commercializing research for innovation. Lack of formal link between the public and private sectors, university and NGOs which can be more conducive for innovation activities (Zaparucha \& Muths, 2014). In additional to that author wasn't surprised with the low impact of collaboration and technology acquisition network in innovation performance results because of how Tanzania citizens perceive innovation concept. The concept is still associated to heavy industry technology and invention only, which seem not applicable in other type of firms.

The finding obtained can be source of primary design of diversity network management strategy but the innovation episode should be considered. Veugelers and Cassiman, 1999 suggested firms to focus on collaboration and technology acquisition during the development stage of innovation. Larsen and Salter, 2006 suggested firms to focus on information exploration and exploitation during the early stage of innovation. 


\section{Macrothink}

Journal of Entrepreneurship and Business Innovation

ISSN 2332-8851

2018, Vol. 5, No. 1

\section{Limitation and Future Research}

Despite the reliability of well information collected through survey using qualified questionnaire which contribution considered all factors important in asking questions and secondary data from Tanzania bureau of statistics there are some limitations in the study. This study focused on diversity of network which measured by quantity of the each network company can employ and ignore the degree of the usage of the network. Some details couldn't observed due to time factor and therefore has being left for future research. Future researcher should focus the degree of usage of the network to find the quality of network usage and its impact on innovation performance. In additional to that, this study cannot be generalized on the whole Tanzania population, due to the fact that, sample used was from Tanzania Bureau of statistics database and which concentrated only on few innovative firms around the country.

\section{References}

Ahuja, G. (2000). Collaboration networks, structural holes, and innovation: A longitudinal study. Administrative Science Quarterly, 45(3), 425-455.

Ahuja, G., \& Katila, R. (2001). Technological acquisitions and the innovation performance of acquiring firms: A longitudinal study. Strategic Management Journal, 22(3), 197-220.

Ahuja, G., \& Morris Lampert, C. (2001). Entrepreneurship in the large corporation: A longitudinal study of how established firms create breakthrough inventions. Strategic Management Journal, 22(6-7), 521-543.

Allison, P. D. (1999). Multiple regression: A primer. Pine Forge Press.

Amara, N., \& Landry, R. (2005). Sources of information as determinants of novelty of innovation in manufacturing firms: evidence from the 1999 statistics Canada innovation survey. Technovation, 25(3), 245-259.

Arundel, A., \& Kemp, R. (2009). Measuring eco-innovation.

Baldwin, C., \& Von Hippel, E. (2011). Modeling a paradigm shift: From producer innovation to user and open collaborative innovation. Organization Science, 22(6), 1399-1417.

Bamieh, B., Jovanovic, M. R., Mitra, P., \& Patterson, S. (2012). Coherence in large-scale networks: Dimension-dependent limitations of local feedback. IEEE Transactions on Automatic Control, 57(9), 2235-2249.

Baum, J. A., Calabrese, T., \& Silverman, B. S. (2000). Don't go it alone: Alliance network composition and startups' performance in Canadian biotechnology. Strategic Management Journal, 267-294.

Bloch, C. (2007). Assessing recent developments in innovation measurement: the third edition of the Oslo Manual. Science and Public Policy, 34(1), 23-34.

Boschma, R. A., \& Ter Wal, A. L. (2007). Knowledge networks and innovative performance in an industrial district: the case of a footwear district in the South of Italy. Industry and 
Innovation, 14(2), 177-199.

Bougrain, F., \& Haudeville, B. (2002). Innovation, collaboration and SMEs internal research capacities. Research Policy, 31(5), 735-747.

Caloghirou, Y., Kastelli, I., \& Tsakanikas, A. (2004). Internal capabilities and external knowledge sources: complements or substitutes for innovative performance? Technovation, 24(1), 29-39.

Castles, I. (1997). Review of the OECD-Eurostat PPP Program. report commissioned by the OECD. Retrieved from http://www. oecd. org/pdf M, 19000

Chesbrough, H. (2003). The logic of open innovation: managing intellectual property. California Management Review, 45(3), 33-58.

Chesbrough, H., Vanhaverbeke, W., \& West, J. (2006). Open innovation: Researching a new paradigm. Oxford University Press on Demand.

Christensen, J., \& Drejer, I. (2005). The strategic importance of location: Location decisions and the effects of firm location on innovation and knowledge acquisition. European Planning Studies, 13(6), 807-814.

Chung, S. A., \& Kim, G. M. (2003). Performance effects of partnership between manufacturers and suppliers for new product development: The supplier's standpoint. Research Policy, 32(4), 587-603.

Cohen, W. M., \& Levinthal, D. A. (1990). Absorptive capacity: A new perspective on learning and innovation. Administrative Science Quarterly, 128-152.

Cooke, P., \& Wills, D. (1999). Small firms, social capital and the enhancement of business performance through innovation programmes. Small Business Economics, 13(3), 219-234.

Damanpour, F., Walker, R. M., \& Avellaneda, C. N. (2009). Combinative effects of innovation types and organizational performance: A longitudinal study of service organizations. Journal of Management Studies, 46(4), 650-675.

Daniel Kindström, D. C. K., Dr, Nätti, S., Hurmelinna-Laukkanen, P., \& J. Johnston, W. (2014). Absorptive capacity and network orchestration in innovation communities-promoting service innovation. Journal of Business \& Industrial Marketing, 29(2), 173-184.

Davis, G. F., \& Adam Cobb, J. (2010). Chapter 2 Resource dependence theory: Past and future Stanford's organization theory renaissance, 1970-2000 (pp. 21-42). Emerald Group Publishing Limited.

De Jong, J. P., Bruins, A., Dolfsma, W., \& Meijaard, J. (2003). Innovation in service firms explored: what, how and why: EIM Report, Zoetermeer.

De Jong, J. P., \& Vermeulen, P. A. (2006). Determinants of product innovation in small firms: A comparison across industries. International Small Business Journal, 24(6), 587-609.

Denis, D. J. (2004). Entrepreneurial finance: an overview of the issues and evidence. Journal 
of Corporate Finance, 10(2), 301-326.

Dhanaraj, C., \& Parkhe, A. (2006). Orchestrating innovation networks. Academy of Management Review, 31(3), 659-669.

Drucker, P. F. (1985). The discipline of innovation. Harvard Business Review, 63(3), 67-72.

Evangelista, R. (2000). Sectoral patterns of technological change in services. Economics of innovation and new technology, 9(3), 183-222.

Evangelista, R., \& Sirilli, G. (1995). Measuring innovation in services. Research evaluation, 5(3), 207-215.

Faems, D., Van Looy, B., \& Debackere, K. (2003). The role of inter-organizational collaboration within innovation strategies: Towards a portfolio approach.

Fosfuri, A., \& Tribó, J. A. (2008). Exploring the antecedents of potential absorptive capacity and its impact on innovation performance. Omega, 36(2), 173-187.

Frenz, M., \& Ietto-Gillies, G. (2009). The impact on innovation performance of different sources of knowledge: Evidence from the UK Community Innovation Survey. Research Policy, 38(7), 1125-1135.

Gallouj, F. (2002). Innovation in the service economy: the new wealth of nations: Edward Elgar Publishing.

Gallouj, F., \& Weinstein, O. (1997). Innovation in services. Research Policy, 26(4-5), 537-556.

Gavetti, G., \& Levinthal, D. (2000). Looking forward and looking backward: Cognitive and experiential search. Administrative Science Quarterly, 45(1), 113-137.

Gunday, G., Ulusoy, G., Kilic, K., \& Alpkan, L. (2011). Effects of innovation types on firm performance. International Journal of production economics, 133(2), 662-676.

Hagedoorn, J. (1993). Understanding the rationale of strategic technology partnering: Nterorganizational modes of cooperation and sectoral differences. Strategic Management Journal, 14(5), 371-385.

Hagedoorn, J. (2002). Inter-firm R\&D partnerships: an overview of major trends and patterns since 1960. Research Policy, 31(4), 477-492.

Hauknes, J., \& Rj, G. (1998). Services in innovation-Innovation in services. Paper presented at the STEP report R13/1998. STEP Group.

Howells, J., Tether, B., Gallouj, F., Djellal, F., Gallouj, C., Blind, K., . . Corrocher, N. (2004). Innovation in Services: Issues at Stake and Trends. European Commission.

Huang, F., \& Rice, J. (2009). The role of absorptive capacity in facilitating" Open innovation" outcomes: A study of Australian SMEs in the manufacturing sector. International Journal of Innovation Management, 13(02), 201-220. 


\section{Macrothink}

Journal of Entrepreneurship and Business Innovation

ISSN 2332-8851

2018, Vol. 5, No. 1

Hurmelinna-Laukkanen, P., \& Ritala, P. (2010). Protection for profiting from collaborative service innovation. Journal of Service Management, 21(1), 6-24.

Jennings, P., \& Beaver, G. (1997). The performance and competitive advantage of small firms: a management perspective. International Small Business Journal, 15(2), 63-75.

Jensen, R. (2007). The digital provide: Information (technology), market performance, and welfare in the South Indian fisheries sector. The Quarterly Journal of Economics, 122(3), $879-924$.

Jones, E., Harrison, D., \& McLaren, J. (2001). Managing Creative Eco-innovation-Structuring outputs from Eco-innovation projects. The Journal of Sustainable Product Design, 1(1), 27-39.

Katila, R., \& Ahuja, G. (2002). Something old, something new: A longitudinal study of search behavior and new product introduction. Academy of Management Journal, 45(6), 1183-1194.

Katila, R., Rosenberger, J. D., \& Eisenhardt, K. M. (2008). Swimming with sharks: Technology ventures, defense mechanisms and corporate relationships. Administrative Science Quarterly, 53(2), 295-332.

Kotabe, M., Jiang, C. X., \& Murray, J. Y. (2017). Examining the complementary effect of political networking capability with absorptive capacity on the innovative performance of emerging-market firms. Journal of Management, 43(4), 1131-1156.

Kotlarsky, J., \& Oshri, I. (2005). Social ties, knowledge sharing and successful collaboration in globally distributed system development projects. European Journal of Information Systems, 14(1), 37-48.

Kwong, C., Jones-Evans, D., \& Thompson, P. (2012). Differences in perceptions of access to finance between potential male and female entrepreneurs: Evidence from the UK. International Journal of Entrepreneurial Behavior \& Research, 18(1), 75-97.

Lam, A. (1997). Embedded firms, embedded knowledge: Problems of collaboration and knowledge transfer in global cooperative ventures. Organization Studies, 18(6), 973-996.

Larson, A. (1992). Network dyads in entrepreneurial settings: A study of the governance of exchange relationships. Administrative Science Quarterly, 76-104.

Laursen, K., \& Salter, A. (2006). Open for innovation: the role of openness in explaining innovation performance among UK manufacturing firms. Strategic Management Journal, 27(2), 131-150.

Lee, S., Park, G., Yoon, B., \& Park, J. (2010). Open innovation in SMEs-An intermediated network model. Research Policy, 39(2), 290-300.

Lundvall, B. (1992). User-Producer Realationships, National Systems of Innovation and Internalisation. Lundvall B.-Å.(a cura di), National Systems of innovation. Towards a theory of innovation and interactive learning, Printer Publisher, London. 
March, J. G. (1991). Exploitation and exploration in Organizational learning. Organization Science, 2, 71-87.

Martínez - Sánchez, A., Vela - Jiménez, M. J., Pérez - Pérez, M., \& De - Luis - Carnicer, P. (2009). Inter - organizational cooperation and environmental change: moderating effects between flexibility and innovation performance. British Journal of Management, 20(4), 537-561.

McAdam, R., McConvery, T., \& Armstrong, G. (2004). Barriers to innovation within small firms in a peripheral location. International Journal of Entrepreneurial Behavior \& Research, 10(3), 206-221.

McGee, J. E., \& Sawyerr, O. O. (2003). Uncertainty and information search activities: a study of owner - managers of small high - technology manufacturing firms. Journal of Small Business Management, 41(4), 385-401.

McManus, T., Holtzman, Y., Lazarus, H., \& McManus, T. (2008). The business strategy/corporate social responsibility "mash-up". Journal of Management Development, 27(10), 1066-1085.

Miles, R. E., Miles, G., \& Snow, C. C. (2005). Collaborative entrepreneurship: How communities of networked firms use continuous innovation to create economic wealth: Stanford University Press.

Naudé, W., Szirmai, A., \& Goedhuys, M. (2011). Innovation and entrepreneurship in developing countries: UNU.

Ngo, L. V., \& O'Cass, A. (2013). Innovation and business success: The mediating role of customer participation. Journal of Business Research, 66(8), 1134-1142.

Nieto, M. J., \& Santamaría, L. (2007). The importance of diverse collaborative networks for the novelty of product innovation. Technovation, 27(6), 367-377.

Oecd, E. (2005). Oslo Manual. Guidelines for Collecting and Interpreting Innovation Data.

Oke, A. (2007). Innovation types and innovation management practices in service companies. International Journal of Operations \& Production Management, 27(6), 564-587.

Ortiz-de-Urbina-Criado, M., Montoro-Sánchez, Á., \& Mora-Valentín, E. M. (2012). Do firm's sector and size influence on the degree of inbound open innovation? International Journal of Transitions and Innovation Systems, 2(2), 169-193.

Parida, V., Westerberg, M., \& Frishammar, J. (2012). Inbound open innovation activities in high - tech SMEs: the impact on innovation performance. Journal of Small Business Management, 50(2), 283-309.

Phelps, C., Heidl, R., \& Wadhwa, A. (2012). Knowledge, networks, and knowledge networks: A review and research agenda. Journal of Management, 38(4), 1115-1166.

Rogers, M. (2004). Networks, firm size and innovation. Small Business Economics, 22(2), 
141-153.

Rosenbusch, N., Brinckmann, J., \& Bausch, A. (2011). Is innovation always beneficial? A meta-analysis of the relationship between innovation and performance in SMEs. Journal of Business Venturing, 26(4), 441-457.

Rothwell, R. (1994). Towards the fifth-generation innovation process. International Marketing Review, 11(1), 7-31.

Rubalcaba, L., Michel, S., Sundbo, J., Brown, S. W., \& Reynoso, J. (2012). Shaping, organizing, and rethinking service innovation: a multidimensional framework. Journal of Service Management, 23(5), 696-715.

Schumpeter, J. (1934). The Theory of Economic Development (translated by Redvers Opie) Harvard University Press. Cambridge, MA.

Spekman, R. E., Salmond, D. J., \& Lambe, C. J. (1997). Consensus and collaboration: norm-regulated behaviour in industrial marketing relationships. European Journal of Marketing, 31(11/12), 832-856.

Teece, D. J. (1986). Profiting from technological innovation: Implications for integration, collaboration, licensing and public policy. Research Policy, 15(6), 285-305.

Tether, B. S. (2002). Who co-operates for innovation, and why: an empirical analysis. Research Policy, 31(6), 947-967.

Tether, B. S. (2005). Do services innovate (differently)? Insights from the European innobarometer survey. Industry \& Innovation, 12(2), 153-184.

Tsai, K. H. (2009). Collaborative networks and product innovation performance: Toward a contingency perspective. Research Policy, 38(5), 765-778.

Tsai, K. H., \& Wang, J.-C. (2008). External technology acquisition and firm performance: A longitudinal study. Journal of Business Venturing, 23(1), 91-112.

Ulusoy, G., Çetindamar, D., Yeğenoğlu, H., \& Bulut, Ç. (2007). An Empirical study on the competitiveness and innovation in four sectors of the Turkish manufacturing industry.

Vega-Jurado, J., Gutiérrez-Gracia, A., \& Fernández-de-Lucio, I. (2009). Does external knowledge sourcing matter for innovation? Evidence from the Spanish manufacturing industry. Industrial and Corporate Change, 18(4), 637-670.

Veugelers, R. (1998). Collaboration in R\&D: an assessment of theoretical and empirical findings. De economist, 146(3), 419-443.

Von Corswant, F., \& Tunälv, C. (2002). Coordinating customers and proactive suppliers: A case study of supplier collaboration in product development. Journal of Engineering and Technology Management, 19(3-4), 249-261.

Wadhwa, A., Phelps, C., \& Kotha, S. (2016). Corporate venture capital portfolios and firm innovation. Journal of Business Venturing, 31(1), 95-112. 


\section{Macrothink}

Journal of Entrepreneurship and Business Innovation

ISSN 2332-8851 2018, Vol. 5, No. 1

Wang, Q., \& Gao, S. (2011). Network architecture and firm performance: A resources-based view. Frontiers of Business Research in China, 5(4), 559-579.

Zeng, S. X., Xie, X. M., \& Tam, C. M. (2010). Relationship between cooperation networks and innovation performance of SMEs. Technovation, 30(3), 181-194.

\section{Copyright Disclaimer}

Copyright for this article is retained by the author (s), with first publication rights granted to the journal.

This is an open-access article distributed under the terms and conditions of the Creative Commons Attribution license (http://creativecommons.org/licenses/by/3.0/). 